\title{
In a Complete Systematic Land Registration Program, the Precautionary Principle is Used When Issuing Land Certificates
}

\author{
Lego Karjoko ${ }^{1}$, I Gusti Ayu Ketut Rachmi Handayani ${ }^{2}$, Abdul Kadir Jaelani ${ }^{3}$ Rizal Palil $^{4}$ \\ ${ }^{1.2 .3}$ Universitas Sebelas Maret, Surakarta, Indonesia \\ ${ }^{4}$ Universitas Kebangsaan Malaysia, Malaysia \\ legokarjoko@staff.uns.ac.id.
}

\begin{abstract}
This study aims to determine whether the National Land Agency has applied the precautionary principle to the Complete Systematic Land Registration program or not and to see the implications of land registration through the program. The proposed problem is whether BPN has applied the precautionary principle to the PTSL Program in the impact of Land Registration in the PTSL Program. The approach used is empirical juridical, where this approach is carried out to analyze the extent to which the rules/laws apply effectively. The data obtained were through interviews at BPN. The results of this study can be concluded that using the precautionary principle of BPN in the issuance of land certificates in the PTSL program has been appropriately implemented. However, there are still obstacles experienced, such as the lack of clarity of data collected by participants in this program and incomplete data collected.
\end{abstract}

Keywords- Land, Registration, Indonesia.

\section{INTRODUCTION}

Simple, secure, inexpensive, up-to-date, and open concepts are employed in land registration. Measurement, mapping, land bookkeeping, registration of land rights, and the transfer of these rights are all part of the land registration process, which provides documentation of ownership that can be used as solid evidence. Land registration activities for the first time and land registration data maintenance are governed by PP No. 24 of 1997.[1]

The government, through the National Defense Agency (BPN), registers land parcels that have not been verified based on a long-term and annual work plan and in areas designated by the State Minister of Agrarian Affairs/Head of BPN. The State Minister for Agrarian Affairs, on the other hand, has the authority to conduct occasional land registration. Landowners who do not have their plots of land registered. Due to a lack of knowledge about land registration, certificate ownership is absent. The surface of the earth.[2]

BPN organizes a Complete Systematic Land Registration (PTSL) program, which is regulated in the
Regulation of the Minister of Agrarian Affairs and Spatial Planning/Head of the National Land Agency of the Republic of Indonesia Number 12 of 2017 concerning Acceleration of Complete Systematic Land Registration, to ensure equal distribution of land ownership and land conflicts. The government will fund the big budget of this program from multiple sources in order to address the problem of land conflicts.[3]

PTSL is one of the land registration activities that is being carried out simultaneously for the first time in Indonesia for all land registration objects in one village area or the equivalent, and it entails collecting and determining physical truth and legal data for one or more things of registration. Land that will be used for registration. Gunungkidul Regency is one of the areas targeted by this initiative. Gunungkidul Regency covers $1,485.36 \mathrm{~km} 2$, or around 46.63 percent of the Special Region of Yogyakarta's total area. There are 18 subdistricts, 144 villages, and 1,431 padukuhans in Gunungkidul Regency. Gunungkidul has been assigned a quota of 173,686 PTSL that must be finished by 2020. In 2019, 149,500 acres of land were certified, with the remaining 24,186 acres will be certified in 2020.[4]

There are still many people or legal companies that have not registered their land in Gunungkidul Regency, resulting in a paucity of land ownership certificates. Individuals or business entities can use this program to register their land and acquire a land ownership certificate. Each region that participates in the PTSL program is given an objective by the government. So that just a few people/legal entities who fit the criteria can participate. Each area is assigned a goal of around 100 lands to certify. As a result, BPN established an Adjudication Committee as well as a task group (Satgas). A physical task force, a legal task force, and an administrative task force will aid the Adjudication Committee. When collecting biological and legal data, the Land Office's Head must guarantee that the data created by PTSL activities is compatible with electronic data and KKP applications. The PTSL adjudication committee then undertook research to prove rights. [5]

Land disputes can be observed as a result of irregularities in land administration, affecting both landowners and villages, as well as the Land Office as the authorized entity in the land sector. Boundaries and 
overlaps are still a source of contention. As a result, the Land Office's Head must use the precautionary approach to reduce errors. People or legal entities that do not yet have a certificate of ownership of land can receive one through the PTSL program, and the certificate can be utilized as a legal force in the event of a disagreement, as the issuing of the certificate involves many people's rights, and assessing land is not cheap.[6]

\section{RESERCH METHOD}

Field research is the name for this type of study (field research). Field research entails conducting research in the field or on the subject of investigation. The National Land Agency (BPN) in Gunungkidul Regency will be used as a source of data and information for the PTSL program's application of the precautionary principle in land registration.[7] This is a qualitative study in which the data is analyzed and the theoretical foundation must be based on the realities on the ground. The approach method that will be employed is empirical juridical, based on the problem formulation and study objectives stated above. This method is used to determine the extent to which the rules/laws are applied effectively. The precautionary principle of BPN in issuing certifications is cited as the legal basis in this case. The empirical, on the other hand, is used to determine the extent to which this principle is utilized.[8]

\section{FINDINGS AND DISCUSSION}

\section{Prudential Principles of the National Land Agency}

Fake certificates and other documents, as well as fabrication of land documents, are all tied to the performance of the bureaucracy that handles land registration. The rules of Article 32 paragraph (2) of PP No. 24 of 2007 provide that if a certificate is not claimed within 5 years of its issuance, the person who owns the land loses the right to raise an objection/claim against its issuance, or in other words, the actual owner may lose his land rights.[9]

In addition to the procedures for collecting, processing, storing, and presenting correct data, physical data and juridical data are necessary under Article 19 paragraph (2) letter c of the BAL, which states that the certificate of evidence of rights granted is valid as a strong means of proof. As a result, to produce proper data, individuals who have the authority as the executor of land registration must apply the precautionary principle so that there are no errors, errors, or falsification of data that results in wrong data at each level of land registration.[10]

The precautionary principle is extremely important in Gunungkidul Regency, as evidenced by the high amount of data entry errors and the need to anticipate overlapping certificates. This is critical since the certificate serves as a legal guarantee of land ownership rights as well as evidence for the holder. Various certificates have not been given as a result of a mistake in writing personal data from the right holder, despite the fact that the PTSL program has been implemented in several villages in
Gunungkidul Regency for the past three years.[11] The error happened as a result of a lack of attention and precision in data input, as well as a lack of clarity about the rights holder's personal data when the files were acquired. From the stages of the PTSL program and the requirements that must be satisfied by the applicant until the examination and issue of land rights certificates, the precautionary principle is evident. The administrative and field phases must follow the processes outlined in the legislation, double-check the certificate before submitting it, and then begin the process of accounting and issuing of land rights certificates.[12]

\section{Analysis of the Implementation of Prudential Principles in Issuing Land Certificates in Complete Systematic Land Registration Programs}

Land registration can provide legal certainty since it can create proof in the form of a certificate, however Indonesia uses a negative system of land registration, which means the state does not guarantee the accuracy of the information contained in the certificate. However, according to Government Regulation Number 24 of 2007, the negative publication system adopted is not pure, because Article 19 paragraph (2) letter c of the UUPA states that the certificate of proof of rights issued is valid as a strong evidence tool, in addition to the procedure of collecting, processing, storing, and presenting physical and juridical data to present corroboration.[13]

As a result, the precautionary principle must be implemented by the party with authority as the land registration executor to ensure that there are no data inaccuracies, errors, or falsifications that result in wrong data at each level of land registration. Multiple certificates, as well as fraudulent certificates, are common legal issues that can hurt parties with legal ties to land parcels or who want to take legal action against them.[14]

The existence of phony certificates and document falsification, which occur as a result of the bureaucracy that arranges land registration's performance. According to Article 32 paragraph (2) of PP No. 24 of 2007, the party who owns the land loses the right to submit a kebertan or litigation over the issuance of the certificate within 5 years after the certificate is issued, or in other words, the actual owner may lose the right to land ownership. the terrain.[15]

The PTSL program, which involves mass land registration, has gotten excellent feedback from the Gunungkidul community, particularly in Padukuhan Bulurejo, Playen Village, and Terbah Village. Gunungkidul Regency aims to enroll 130,869 parcels of land in this scheme between 2018 and 2020. PTSL is a follow-up to the National Project (PRONA), which took place in 2017. This initiative employs a systematic approach to data collecting on all unregistered land in a given area. As a result, this method was used first to ensure that land registration followed the system based on the current work plans in each region.[16]

A rule that is made and published with confidence because it controls explicitly and logically is known as 
normative legal certainty. Article 19 paragraph (1) of the UUPA controls land registration, stating, "To assure legal certainty by the Government, land registration is held across the Republic of Indonesia according to the provisions governed by Government Regulation." Land tenure has two definitions: physical and legal. According to legal control, it is based on rights that are protected by law and gives the right holder authority to physically manage the land to which he or she is entitled. Individual land tenure rights, as defined by national law, include rights to land, waqf, land ownership rights, mortgage rights, and property rights to flat units.[6]

Systematic land registration is preferable over sporadic land registration since it speeds up the collecting of data on land parcels to be registered. Land certificates, land maps, and land registries are among the PTSL items issued by the Gunungkidul Land Office. The major goal of PTSL is to measure all lands that can't be certified because they don't fulfill the current standards.[17]

The purpose of PTSL is to provide legal certainty to the community regarding land rights. The existence of a certificate can provide this legal assurance. This certificate will become a stronger written evidence in the future, and it must be taken as true until the court proves it with other evidence. The establishment of PTSL may make it easier for the public to get land certificates, as well as provide the government with a single map of land in Indonesia. PTSL activities in Gunungkidul Regency are governed by Regulation of ART/BPN No. 6 of 2018, which deviates from various aspects of Government Regulation No. 24 of 1997, particularly in deferring payment of transitional taxes (BPHTB and/or PPH).[18]

\section{IV.CONCLUSION}

Based on the above description regarding the application of the precautionary principle of BPN in issuing certificates and implementing land registration through a complete systematic land registration program, it can be concluded that the application of the precautionary principle of BPN in issuing certificates to the PTSL program in Gunungkidul Regency has been applied at the data collection stage. Physical and juridical. At this stage, the Measuring Team checks the validity of the data using the GeoKKP (Land Computerization) system, which is then plotted to avoid overlapping certificates. At the stage of issuing certificates, the precautionary principle is still not paid attention to. In this case, when the certificate was published, some certificates still experienced errors in writing names, addresses, places, dates of birth, etc.

\section{REFERENCES}

[1] L. Karjoko, J. Santosa, and I. G. A. K. Rachmi Handayani, "Disfungsi Peraturan PerundangUndangan Tanggung Jawab Sosial dan Lingkungan di Indonesia," J. Huk. Ius Quia Iustum, vol. 26, no. 2, pp. 305-325, 2019.
[2] M. H. Ahmadi, I. G. A. K. R. Handayani, and L. Karjoko, "Problems in law of mortgage right law number 4 Tahun 1997," Int. J. Adv. Sci. Technol., vol. 28, no. 20, pp. 321-324, 2019.

[3] E. Sukmoro, A. Sulistiyono, and L. Karjoko, "The politic of law of PT. Kereta api Indonesia (persero) track access charge policy based on justice," Int. J. Adv. Sci. Technol., vol. 28, no. 20, pp. 353-361, 2019.

[4] L. Karjoko, D. W. Winarno, Z. N. Rosidah, and I. G. A. K. R. Handayani, "Spatial planning dysfunction in East Kalimantan to support green economy," Int. J. Innov. Creat. Chang., vol. 11, no. 8, pp. 259-269, 2020.

[5] Soediro, I. G. A. K. R. Handayani, and L. Karjoko, "The spatial planning to implement sustainable agricultural land," Int. J. Adv. Sci. Technol., vol. 29, no. 3 Special Issue, pp. 1307-1311, 2020.

[6] A. K. Jaelani, I. G. A. K. R. Handayani, and L. Karjoko, "Development of tourism based on geographic indication towards to welfare state," Int. J. Adv. Sci. Technol., vol. 29, no. 3 Special Issue, pp. 1227-1234, 2020.

[7] L. Karjoko, Z. N. Rosidah, and I. G. A. K. R. Handayani, "Refleksi Paradigma Ilmu Pengetahuan Bagi Pembangunan Hukum Pengadaan Tanah Lego," Bestuur, vol. 7, no. 2, pp. 1-14, 2019.

[8] Z. N. Rosidah, "Coherence of the Rules of Sharia Against Pancasila," Bestuur, vol. 8, no. 1, p. 40, 2020.

[9] T. Leonard, E. F. Pakpahan, Heriyati, L. Karjoko, and I. G. A. K. R. Handayani, "Legal review of share ownership in a joint venture company," Int. J. Innov. Creat. Chang., vol. 11, no. 8, pp. 332-345, 2020.

[10] Yuliandri, G. A. K. R. Handayani, T. Prasetyo, K. Seregig, and H. Tegnan, "Retributive justice theory and the application of the principle of sentencing proportionality in Indonesia," J. Leg. Ethical Regul. Issues, vol. 21, no. 4, pp. 1-8, 2018.

[11] I. G. A. K. R. Handayani, A. Sulistiyono, T. Leonard, A. Gunardi, and F. U. Najicha, "Environmental management strategy in mining activities in forest area accordance with the based justice in Indonesia," J. Leg. Ethical Regul. Issues, vol. 21 , no. 2,2018

[12] J. D. Ismoyo, "The Model of Management of the Masela Block Based on People's Welfare in Maluku," Bestuur, vol. 8, no. 2, p. 84, 2020.

[13] I. Gusti Ayu Ketut Rachmi Handayani, R. Martanto, L. Karjoko, A. Kadir Jaelani, and Mukhlishin, "Application of advance data protection system as an efforts to improve Indonesia digital economy," Int. J. Adv. Sci. Technol., vol. 29, no. 4, pp. 1774-1778, 2020.

[14] F. Nihayah, Hawtiwiningsih, and I. G. A. K. R. Handayani, "Politics of law enforcing death sentence based on the benefit of law," Int. J. Adv. Sci. Technol., vol. 28, no. 20, pp. 341-348, 2019.

[15] L. Karjoko, I. G. A. K. R. Handayani, A. S. 
Sudarwanto, D. W. Winarno, A. K. Jaelani, and W. N. Hanum, "THE CONSEQUENCE OF THE DECISION OF THE CONSTITUTIONAL COURT IN FORESTRY ON THE RECOGNITION OF TRADITIONAL FORESTS IN," J. Leg. Ethical Regul. Issues, vol. 24, no. 5, pp. 1-8, 2021.

[16] A. L. S. Sudarwanto et al., "POSITION OF FREEDOM OF CONTRACT PRINCIPLE IN FORESTRY PARTNERSHIP POLICY," J. Leg. Ethical Regul. Issues, vol. 24, no. 5, pp. 1-11, 2021.

[17] I. Iswantoro, "Strategy and Management of Dispute Resolution, Land Conflicts at the Land Office of Sleman Regency," J. Hum. Rights, Cult. Leg. Syst., vol. 1, no. 1, pp. 1-17, 2021.

[18] A. Ma, "Legal Aspects of Environment in Indonesia: an Efforts to Prevent Environmental Damage and Pollution," J. Hum. Rights, Cult. Leg. Syst., vol. 1, no. 1, pp. 18-30, 2021. 